\title{
Analysis of Two Kinds of Chemical Reagents on Improvement of Local Soil Corrosion Environment
}

\author{
Yan-Hua CHEN ${ }^{1, a, *}$, Lin-Lin LIU ${ }^{1, b}$, Liu-Jun LI $^{1, c}$, Dong-Dong LI $^{1, d}$, Mei YANG ${ }^{1, e}$, \\ Lu-Zhen JIANG ${ }^{2, f}$ \\ ${ }^{1}$ North China University of Science and Technology, Tangshan 063009, China \\ ${ }^{2}$ Hebei University of Science and Technology, Shijiazhuang 050018, China \\ acyh427@163.com, b974549693@qq.com, '916130910@qq.com, d602935018@qq.com, \\ eywdym2002@126.com, ${ }^{\mathrm{f}} 13398351 @ q q . c o m$ \\ ${ }^{*}$ Corresponding author
}

Keywords: Soil Environment, Buried Pipeline, Corrosion, Corrosion Inhibitor, Bactericide.

\begin{abstract}
Soil environment is one of main influence factors for buried pipeline corrosion. In order to improve soil corrosion environment, some physical and chemical methods are available. The aim of this work is to evaluate validities of two kinds of chemical reagents for improving soil corrosion environment because of microbiological activity, which includes three corrosion inhibitors and three bactericides. Several groups of laboratory experiments on corrosion simulation are carried. Corrosion rate of steel test piece and sterilization rate of bactericides are calculated. Experimental results show that corrosion inhibitors and bactericides are effective to improve corrosive soil environment, which have different effects on corrosive soil. Optimal reagent and concentration in this work could be obtained. This research can provide effective anti-corrosion measure for buried pipeline.
\end{abstract}

\section{Introduction}

Corrosion is one of main factors for buried metal pipeline damage. And soil is main carrier which causes the metal pipe corroded complexly ${ }^{[1,2]}$. It has been well accepted that microbiological corrosion $(\mathrm{MC})$ is one of the most damaging failure mode for buried pipeline in soils ${ }^{[3]}$. In research soil, sulfate reducing bacteria (SRB) exists universally which induces metal pipe corroded. Soil environment becomes a focus of investigation. Now, many studies of soil characteristics and interaction with the metal surface have carried ${ }^{[4-7]}$, but studies on improving soil environment are few. So, aim at soil, chemical methods on improving local soil environment are investigated.

Corrosion inhibitors and bactericides are widely used in fluid medium within metal pipeline to solve inner corrosion of pipe ${ }^{[8-11]}$. In order to prevent metal pipeline from external corrosion, cathodic protection and anti-corrosive coating materials are adopted in actual pipeline engineering. In this work, soil environment is taken as a focus to improve pipeline corrosion. Also, the idea for solving inner corrosion is applied on soil environment for solving external corrosion of buried metal pipeline. That is corrosion inhibitors and bactericides used in local corrosive soil. Three corrosion inhibitors and bactericides are selected in these experimental researches. Comparisons of these reagents on anti-corrosion are made, and optimal inhibitor and bactericide are obtained for this work.

\section{Research Method}

Corrosion inhibitors and bactericides are used widely in dealing with industry water which induces inner corrosion of metal pipe or equipment. Considered effects of these reagents, Sodium fluorosilicate $\left(\mathrm{Na}_{2} \mathrm{SiF}_{6}\right)$, Sodium benzoate $\left(\mathrm{C}_{6} \mathrm{H}_{5} \mathrm{CO}_{2} \mathrm{Na}\right)$, Sodium dodecyl sulfate $\left(\mathrm{C}_{12} \mathrm{H}_{25} \mathrm{SO}_{4} \mathrm{Na}\right)$ were selected as corrosion inhibitors, Chlorine Dioxide $\left(\mathrm{ClO}_{2}\right)$, Sodium Hypochlorite $(\mathrm{NaClO})$, Glutaric dialdehyde $\left(\mathrm{C}_{5} \mathrm{H}_{8} \mathrm{O}_{2}\right)$ were selected as bactericides. Soil solution specimens were made by spot soil of Daqing Oil field. Then 3 concentrations for corrosion inhibitors and bactericides were 
designed. New and smooth test pieces of $20^{\#}$ steel shown as figure 1(a) were used to observe corrosive phenomenon in corrosion inhibitors experiments. Table 1, 2 shows basic experimental data of corrosion inhibitors and bactericides respectively.

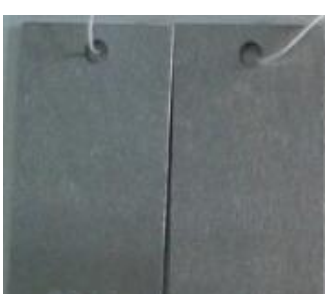

(a)New Steel Piece

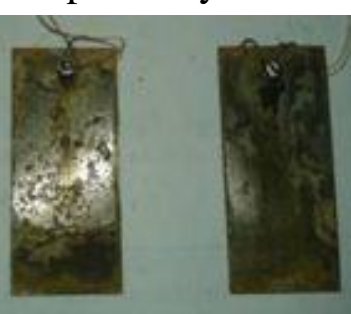

(b)After Corroded

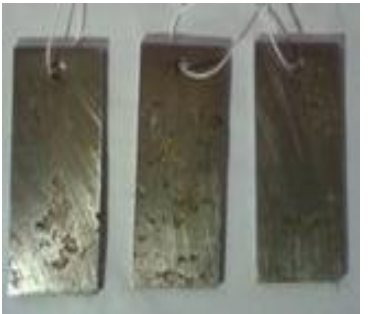

(c)Corrosive Erased

Fig.1 Appearance of $20^{\#}$ Steel Piece during the Whole Experiment

Tab.1 Basic Data of Corrosion Inhibitor Experiment

\begin{tabular}{|c|c|c|c|}
\hline Name of corrosion inhibitors & Concentration $(\mathrm{mg} / \mathrm{L})$ & No. of metal piece & Weight before corrosion $(\mathrm{g})$ \\
\hline \multirow{12}{*}{$\mathrm{Na}_{2} \mathrm{SiF}_{6}$} & \multirow{3}{*}{0} & K(1) & 18.8743 \\
\hline & & $\mathrm{K}(2)$ & 18.5721 \\
\hline & & K(3) & 18.3653 \\
\hline & \multirow{3}{*}{100} & F-11) & 18.0327 \\
\hline & & F-1(2) & 18.4823 \\
\hline & & F-13) & 18.3728 \\
\hline & \multirow{3}{*}{200} & F-2(1) & 18.6303 \\
\hline & & F-2(2) & 18.692 \\
\hline & & F-2(3) & 18.3335 \\
\hline & \multirow{3}{*}{300} & F-31) & 18.534 \\
\hline & & F-3(2) & 18.8175 \\
\hline & & F-3(3) & 18.6092 \\
\hline \multirow{9}{*}{$\mathrm{C}_{6} \mathrm{H}_{5} \mathrm{CO}_{2} \mathrm{Na}$} & \multirow{3}{*}{100} & B-11) & 18.6883 \\
\hline & & B-1(2) & 18.7411 \\
\hline & & B-1(3) & 19.0408 \\
\hline & \multirow{3}{*}{200} & B-2(1) & 18.6627 \\
\hline & & B-2(2) & 18.351 \\
\hline & & B-2(3) & 18.433 \\
\hline & \multirow{3}{*}{300} & B-31) & 20.6643 \\
\hline & & B-3(2) & 18.3579 \\
\hline & & $\mathrm{B}-3(3)$ & 20.6784 \\
\hline \multirow{9}{*}{$\mathrm{C}_{12} \mathrm{H}_{25} \mathrm{SO}_{4} \mathrm{Na}$} & \multirow{3}{*}{100} & S-1(1) & 19.7539 \\
\hline & & S-1(2) & 18.3477 \\
\hline & & S-13) & 18.0558 \\
\hline & \multirow{3}{*}{200} & S-2(1) & 18.4261 \\
\hline & & $\mathrm{S}-2(2)$ & 18.5996 \\
\hline & & S-2(3) & 18.5667 \\
\hline & \multirow{3}{*}{300} & S-31) & 19.0641 \\
\hline & & S-3(2) & 18.9444 \\
\hline & & $\mathrm{S}-3(3)$ & 18.6907 \\
\hline
\end{tabular}

Tab.2 Basic Data of Bactericides Experiment

\begin{tabular}{ccccccc}
\hline Name of bactericides & \multicolumn{5}{c}{ Concentration of solution(mg/L) } \\
\hline $\mathrm{ClO}_{2}$ & 5 & 10 & 20 & 30 & 50 \\
\hline $\mathrm{NaClO}$ & 20 & 30 & 40 & 50 & 60 & 20 \\
\hline $\mathrm{C}_{5} \mathrm{H}_{8} \mathrm{O}_{2}$ & 2.5 & 5 & 10 & 15 & - \\
\hline
\end{tabular}

\section{Results and Discussions}

\section{Corrosion Inhibitors}

When test period of corrosion inhibitors was over, test steel pieces corroded were dealed with. Representative of corroded appearance of test pieces was shown as figure 1(b), (c). Then corrosive 
rate of different concentration of different corrosion inhibitors was calculated, and shown as table 3-5.

Tab.3 Experimental Results of Inhibition Efficiency under Different Concentration of $\mathrm{Na}_{2} \mathrm{SiF}_{6}$

\begin{tabular}{|c|c|c|c|c|c|}
\hline Concentration of $\mathrm{Na}_{2} \mathrm{SiF}_{6}(\mathrm{mg} / \mathrm{L})$ & Weight losing (g) & $\begin{array}{l}\text { Average weight losing } \\
(\mathrm{g})\end{array}$ & $\begin{array}{l}\text { Corrosive rate } \\
\quad(\mathrm{mm} / \mathrm{a})\end{array}$ & $\begin{array}{c}\text { Inhibition } \\
\text { efficiency } \\
(\%)\end{array}$ & Corrosion level \\
\hline 0 & $\begin{array}{l}0.0503 \\
0.0489 \\
0.0567 \\
\end{array}$ & 0.0520 & 0.2814 & $\longrightarrow$ & $\begin{array}{l}\text { Moderate } \\
\text { corrosion }\end{array}$ \\
\hline 100 & $\begin{array}{l}0.0460 \\
0.0423 \\
0.0409 \\
\end{array}$ & 0.0431 & 0.2332 & 17.1 & $\begin{array}{l}\text { Moderate } \\
\text { corrosion }\end{array}$ \\
\hline 200 & $\begin{array}{l}0.0496 \\
0.0437 \\
0.0527 \\
\end{array}$ & 0.0487 & 0.2635 & 6.4 & $\begin{array}{l}\text { Moderate } \\
\text { corrosion }\end{array}$ \\
\hline 300 & $\begin{array}{l}0.0428 \\
0.0379 \\
0.0433\end{array}$ & 0.0413 & 0.2238 & 20.5 & $\begin{array}{l}\text { Moderate } \\
\text { corrosion }\end{array}$ \\
\hline
\end{tabular}

Tab.4 Experimental Results of Inhibition Efficiency under Different Concentration of $\mathrm{C}_{6} \mathrm{H}_{5} \mathrm{CO}_{2} \mathrm{Na}$

\begin{tabular}{|c|c|c|c|c|c|}
\hline $\begin{array}{l}\text { concentration of } \mathrm{C}_{6} \mathrm{H}_{5} \mathrm{CO}_{2} \mathrm{Na} \\
(\mathrm{mg} / \mathrm{L})\end{array}$ & $\begin{array}{l}\text { Weight losing } \\
(\mathrm{g})\end{array}$ & $\begin{array}{l}\text { Average weight losing } \\
\text { (g) }\end{array}$ & $\begin{array}{l}\text { Corrosive rate } \\
\quad(\mathrm{mm} / \mathrm{a})\end{array}$ & $\begin{array}{c}\text { inhibition } \\
\text { efficiency } \\
(\%)\end{array}$ & Corrosion level \\
\hline \multirow[t]{3}{*}{ ( } & 0.0166 & \multirow{3}{*}{0.0193} & \multirow{3}{*}{0.1043} & \multirow{3}{*}{62.9} & \multirow{3}{*}{$\begin{array}{l}\text { Moderate } \\
\text { corrosion }\end{array}$} \\
\hline & 0.0191 & & & & \\
\hline & 0.0221 & & & & \\
\hline \multirow{3}{*}{200} & 0.0168 & \multirow{3}{*}{0.0183} & \multirow{3}{*}{0.0993} & \multirow{3}{*}{64.7} & \multirow{3}{*}{ Light corrosion } \\
\hline & 0.0187 & & & & \\
\hline & 0.0195 & & & & \\
\hline \multirow{3}{*}{300} & 0.0126 & \multirow{3}{*}{0.0120} & \multirow{3}{*}{0.0648} & \multirow{3}{*}{77} & \multirow{3}{*}{ Light corrosion } \\
\hline & 0.0105 & & & & \\
\hline & 0.0128 & & & & \\
\hline
\end{tabular}

From figure 1(a), surface of new test piece is smooth. When these new pieces are immerged in soil solution with different corrosion inhibitor added in, also with different concentration, corrosion levels of these steel pieces were different. From figure 1(b), thin corrosive adhered to surface of steel piece, and corrosive pits are distributed irregularly which can be seen from figure 1(c). Furthermore, from table 3-5, inhibition efficiency of corrosion inhibitor will improve with the increasing of concentration except $\mathrm{Na}_{2} \mathrm{SiF}_{6}$. When concentration of $\mathrm{Na}_{2} \mathrm{SiF}_{6}$ is $200 \mathrm{mg} / \mathrm{L}$, inhibition efficiency of it is the lowest. Inhibition efficiency of $\mathrm{C}_{6} \mathrm{H}_{5} \mathrm{CO}_{2} \mathrm{Na}$ is the best, especially the concentration of $300 \mathrm{mg} / \mathrm{L}$. So, $\mathrm{C}_{6} \mathrm{H}_{5} \mathrm{CO}_{2} \mathrm{Na}$ is the optimal selection of corrosion inhibitor in this research.

Tab.5 Experimental Results of Inhibition Efficiency under Different Concentration of $\mathrm{C}_{12} \mathrm{H}_{25} \mathrm{SO}_{4} \mathrm{Na}$

\begin{tabular}{|c|c|c|c|c|c|}
\hline Concentration of SDS $(\mathrm{mg} / \mathrm{L})$ & $\begin{array}{l}\text { Weight losing } \\
\text { (g) }\end{array}$ & $\begin{array}{l}\text { Average weight losing } \\
(\mathrm{g})\end{array}$ & $\begin{array}{l}\text { Corrosive rate } \\
(\mathrm{mm} / \mathrm{a})\end{array}$ & $\begin{array}{c}\text { inhibition } \\
\text { efficiency } \\
(\%)\end{array}$ & Corrosion level \\
\hline \multirow{3}{*}{100} & 0.0327 & \multirow{3}{*}{0.0338} & \multirow{3}{*}{0.1828} & \multirow{3}{*}{35} & \multirow{3}{*}{$\begin{array}{l}\text { Moderate } \\
\text { corrosion }\end{array}$} \\
\hline & 0.0332 & & & & \\
\hline & 0.0354 & & & & \\
\hline \multirow{3}{*}{200} & 0.0298 & \multirow{3}{*}{0.0315} & \multirow{3}{*}{0.1704} & \multirow{3}{*}{39} & \multirow{3}{*}{$\begin{array}{l}\text { Moderate } \\
\text { corrosion }\end{array}$} \\
\hline & 0.0299 & & & & \\
\hline & 0.0347 & & & & \\
\hline \multirow{3}{*}{300} & 0.0236 & \multirow{3}{*}{0.0220} & \multirow{3}{*}{0.1193} & \multirow{3}{*}{57.6} & \multirow{3}{*}{$\begin{array}{l}\text { Moderate } \\
\text { corrosion }\end{array}$} \\
\hline & 0.0193 & & & & \\
\hline & 0.0232 & & & & \\
\hline
\end{tabular}

\section{Bactericides}

In this research region, grassland, marsh and farmland are distributed. Content of microorganism in soil is very high. Sulfate reducing bacteria(SRB) is main corrosion factor for buried pipeline, so bactericides are used to improving local soil environment. Aiming at $\mathrm{ClO}_{2}, \mathrm{NaClO}$ and $\mathrm{C}_{5} \mathrm{H}_{8} \mathrm{O}_{2}$, contrast tests are done. The results of sterilization rate are shown as table 6-8. 
Tab.6 Sterilization Rate of $\mathrm{ClO}_{2}(\%)$

\begin{tabular}{c|r|r|r|r|r|r}
\hline \multirow{2}{*}{ Time(d) } & \multicolumn{7}{|c}{ Concentration of $\mathrm{ClO}_{2}(\mathrm{mg} / \mathrm{L})$} \\
\cline { 2 - 7 } & 5 & 10 & 20 & 30 & 40 & 50 \\
\hline 4 & 98.4 & 100 & 100 & 100 & 100 & 100 \\
5 & 97.2 & 100 & 100 & 100 & 100 & 100 \\
6 & 97.2 & 98.8 & 100 & 100 & 100 & 100 \\
7 & 94 & 97.2 & 98.8 & 100 & 100 & 100 \\
8 & 94 & 97.2 & 98.8 & 100 & 100 & 100 \\
9 & 94 & 97.2 & 97.6 & 100 & 100 & 100 \\
10 & 94 & 97.2 & 97.6 & 100 & 100 & 100 \\
11 & 94 & 97.2 & 94 & 100 & 100 & 100 \\
12 & 94 & 97.2 & 94 & 100 & 98.4 & 100 \\
13 & 94 & 97.2 & 94 & 98.8 & 98.4 & 100 \\
14 & 94 & 97.2 & 94 & 98.8 & 98.4 & 100 \\
\hline
\end{tabular}

From table 6-8, the sterilization effect of three bactericides is, $\mathrm{C}_{5} \mathrm{H}_{8} \mathrm{O}>\mathrm{ClO}_{2}>\mathrm{NaClO}$. Table 9 shows that sterilization rate of $\mathrm{C}_{5} \mathrm{H}_{8} \mathrm{O}$ will increase with the increase of its concentration, and sterilization rate is almost $100 \%$ from concentration $2.5 \mathrm{mg} / \mathrm{L}$ to $10 \mathrm{mg} / \mathrm{L}$. When the concentration of $\mathrm{C}_{5} \mathrm{H}_{8} \mathrm{O}$ keeps on increasing, sterilization rate arrives at the maximum. Table 7 shows that sterilization effect of $\mathrm{NaClO}$ is not obvious with the increase of its concentration, and sterilization rate is the highest at concentration $70 \mathrm{mg} / \mathrm{L}$ which approaches the sterilization effect of concentration $60 \mathrm{mg} / \mathrm{L}$. When the concentration is lower than $30 \mathrm{mg} / \mathrm{L}$, the effect of sterilization is very bad. Table 6 shows that sterilization rate of $\mathrm{ClO}_{2}$ is higher than $94 \%$. When the concentration of $\mathrm{ClO}_{2}$ is larger than $30 \mathrm{mg} / \mathrm{L}$, sterilization rate is nearly $100 \%$.

Furthermore, during the experimental period, sterilization rate decreases with the increase of sterilization time, which is related with growth time of bacteria. Because experimental period include cultivating SRB and sterilization of bactericide, there is no SRB during initial stage and sterilization rate of bactericide is $100 \%$. SRB will increase with the time longer, and sterilization effect of bactericide is visualized which is decreasing.

Finally, optimal concentration of these bactericide in this research are $\mathrm{ClO}_{2} 30 \mathrm{mg} / \mathrm{L}, \mathrm{NaClO}$ $70 \mathrm{mg} / \mathrm{L}, \mathrm{C}_{5} \mathrm{H}_{8} \mathrm{O} 10 \mathrm{mg} / \mathrm{L}$, respectively.

Tab.7 Sterilization Rate of $\mathrm{NaClO}(\%)$

\begin{tabular}{c|r|r|r|r|r|c}
\hline \multirow{2}{*}{ Time(d) } & \multicolumn{7}{|c}{ Concentration of $\mathrm{NaClO}(\mathrm{mg} / \mathrm{L})$} \\
\cline { 2 - 7 } & 20 & 30 & 40 & 50 & 60 & 70 \\
\hline 4 & 98.8 & 98.8 & 98.8 & 98.4 & 100 & 100 \\
5 & 95.6 & 82 & 97.2 & 98.4 & 98.4 & 98.4 \\
6 & 88 & 82 & 94.4 & 94.4 & 98.4 & 98.4 \\
7 & 88 & 54 & 82 & 94.4 & 98.4 & 98.4 \\
8 & 88 & 54 & 82 & 90 & 94.4 & 98.4 \\
9 & 88 & 54 & 82 & 90 & 94.4 & 98.4 \\
10 & 88 & 54 & 82 & 90 & 94.4 & 98.4 \\
11 & 88 & 54 & 82 & 90 & 94.4 & 98.4 \\
12 & 0 & 54 & 82 & 90 & 94.4 & 98.4 \\
13 & 0 & 54 & 82 & 90 & 94.4 & 98.4 \\
14 & 0 & 54 & 82 & 90 & 94.4 & 98.4 \\
\hline
\end{tabular}

Tab.8 Sterilization Rate of $\mathrm{C}_{5} \mathrm{H}_{8} \mathrm{O}(\%)$

\begin{tabular}{c|c|c|c|c|c}
\hline \multirow{2}{*}{ Time(d) } & \multicolumn{5}{|c}{ Concentration of $\mathrm{C}_{5} \mathrm{H}_{8} \mathrm{O}$ mg/L } \\
\cline { 2 - 5 } & 2.5 & 5 & 10 & 15 & 20 \\
\hline 4 & 100 & 100 & 100 & 100 & 100 \\
5 & 100 & 100 & 100 & 100 & 100 \\
6 & 98.8 & 100 & 100 & 100 & 100 \\
7 & 98.8 & 98.8 & 100 & 100 & 100 \\
8 & 97.2 & 97.6 & 100 & 100 & 100 \\
9 & 97.2 & 97.6 & 100 & 100 & 100 \\
10 & 97.2 & 97.6 & 100 & 100 & 100 \\
11 & 97.2 & 97.6 & 100 & 100 & 100 \\
12 & 95.6 & 97.6 & 100 & 100 & 100 \\
13 & 95.6 & 97.6 & 100 & 100 & 100 \\
14 & 95.6 & 97.6 & 98.4 & 100 & 100 \\
\hline
\end{tabular}




\section{Summary}

In order to improve local soil environment surrounding buried pipeline, the effects of corrosion inhibitors and bactericides are investigated by laboratory tests. Some conclusions are obtained.

(1) Corrosion inhibitor and bactericide with proper concentration can be used in corrosion soil to improve soil environment and prevent buried pipeline corroded.

(2) Corrosion levels of steel pieces were different with different corrosion inhibitor. Also, inhibition efficiency of corrosion inhibitor will improve with the increasing of concentration except $\mathrm{Na}_{2} \mathrm{SiF}_{6}$.

(3) $\mathrm{C}_{6} \mathrm{H}_{5} \mathrm{CO}_{2} \mathrm{Na}$ with the concentration of $300 \mathrm{mg} / \mathrm{L}$ is the optimal selection of corrosion inhibitor in this research.

(4) The order of sterilization effect of three bactericides is, $\mathrm{C}_{5} \mathrm{H}_{8} \mathrm{O}>\mathrm{ClO}_{2}>\mathrm{NaClO}$. And optimal concentration of these bactericide in this research are $\mathrm{ClO}_{2} 30 \mathrm{mg} / \mathrm{L}, \mathrm{NaClO} 70 \mathrm{mg} / \mathrm{L}, \mathrm{C}_{5} \mathrm{H}_{8} \mathrm{O} 10 \mathrm{mg} / \mathrm{L}$, respectively.

\section{Acknowledgement}

This paper is supported by the National Science Foundation of China(No.51378172, 51308182) and the Natural Science Foundation of Hebei Province(No.E2014209089, E2014208143).

\section{References}

[1] I.S. Cole, D. Marney, The science of pipe corrosion: A review of the literature on the corrosion of ferrous metals in soils, Corrosion Science. 56(2012) 5-16.

[2] Vanessa de Freitas Cunha Lins, Mitchel Leonard Magalhães Ferreira, Patrícia Alves Saliba, Corrosion Resistance of API X52 Carbon Steel in Soil Environment, Journal of Materials Research and Technology, 1(2012) 161-166.

[3] T.Q.Wu, J.Xu, C.Sun, et al. Microbiological corrosion of pipeline steel under yield stress in soil environment, Corrosion Science, 88(2014) 291-305.

[4] C.A.M. Ferreira, J.A.C. Ponciano, D.S. Vaitsman,et al., Evaluation of the corrosivity of the soil through its chemical composition, Sci. Total Environ. 388(2007) 250-255.

[5] M. Sancy, Y. Gourbeyre, E.M.M. Sutter, et al., Mechanism of corrosion of cast iron covered by aged corrosion products: application of electrochemical impedance pectrometry, Corrosion Sci. 52(2010) 1222-1227.

[6] Y.H. Wu, T.M. Liu, S.X. Luo, et al., Corrosion characteristics of Q235 steel in simulated Yingtan soil solutions, Materialwiss. Werkstofftech. 41 (2010) 142-146.

[7] Y.H. Wu, T.M. Liu, C. Sun, et al., Effects of simulated acid rain on corrosion behaviour of Q235 steel in acidic soil, Corros. Eng. Sci. Technol. 45 (2010) 136-141.

[8] D.A. Lopez, S. N. Simison, Inhibitors Performance In $\mathrm{CO}_{2}$ Corrosion-EIS Studies On The Interaction Between Their Molecular Structure and Steel Microstructure, Corrosion Science, 47 (2005) 735-755.

[9] H.J.Choi, R.L.Cepulis, Inhibitor film persistence measurements in carbon dioxide environments, Materials Performance, 28(2003) 87-93.

[10] H.Y.Du, M.X.LU, Y.S.WU,et al., Study of inhibiton mechanism of stearamide derivative on CO2 corroded steel X65, Acta Metallurgica Sinica, 42(2006) 533-536.

[11] M.D.Yang, Development on new inhibiton of high temperature for anti $\mathrm{H}_{2} \mathrm{~S} / \mathrm{CO}_{2}$ corrosion, South-west Petroleum University, Chengdu, 2013. 